\title{
Primary Sources of Diamonds in the Birim Area, Ghana
}

\author{
Kaminsky, F.V. ' , Gorzynsky, G. ${ }^{2}$, Sablukova, L.I. ${ }^{3}$, Sablukov, S.M. ${ }^{3}$, and Zakharchenko,
} O.D. ${ }^{3}$

1. KM Diamond Exploration Ltd., 815 Evelyn Drive, West Vancouver, B.C., Canada, V7T 1J1, tel. \& fax (604) 925-8755, Email: kaminsky@fox.nstn.ca

2. Carlin Resources Corp., 540 - 355 Burrard Street, Vancouver, B.C., Canada V6C 2G8

3. Institute of Diamonds, Russian Academy of Natural Sciences, $155-5 / 10$ Litovskii Blvd., Moscow, Russia 117593

The Birim area is the main diamondiferous area in Ghana. It is situated in the Birim River drainage basin, and is dominated by metamorphosed greywackes, phyllites, crystalline schists, metamorphosed basic, ultrabasic and pyroclastic rocks of the Birim formation, granites and granodiorites and dykes of acid rocks. Diamondiferous placers are known to be present in some areas of the river's watercourse and along its left and right affluents. More than 100 million carats of diamonds have been recovered from these placers since the 1920s. There were no known primary diamond deposits in the Birim area.

Diamonds. Rounded-dodecahedral and octahedral (both flat faced octahedra and rare rounded octahedroids) crystals are predominant among the diamonds from the Birim area. A high proportion of twins and aggregates is specific to these diamonds: it varies in different areas from 5.2 to $33.0 \%$. A few combination-type diamonds and single cubic-habit crystals have been found. There appears to be a correlation between the morphology and size of diamonds: the finer the crystals are, the higher is the proportion of octahedra among them. Many of the diamonds studied bear marks of natural resorption, which manifests itself in etch channels, patterns and caverns and a corrosioninduced fabric on the crystal surfaces.

The majority of the diamonds from the placers of the Birim area are colorless. The less numerous colored stones are predominantly smoky-brown and gray. The coloration is epigenetic. There are also two pale green crystals; their coloration is caused by abundant pigmentation spots.

Pigmentation spots and their clusters are rather common for the Ghanaian diamonds. The spots are typically pale grayish-green in color. In some cases, pigmentation spots are colored bright-green or, rarely, light-brown.

The most typical erosion evidence shown by diamonds are glossy spallation surfaces with sharp edges developed to different extents, from the smallest pits on the edges of intact crystals to acuteangular fragments spalled on all sides. Such spallation surfaces, much like the surfaces of spalled crystals, typically bear no direct evidence of erosion: only their thin, sharp edges are fractured and crumbled. No crescentiform and annular fissures, rhombic patterns or abrasions dulling the faces or blunting and rounding of edges and apices have been noted in the diamonds studied. The fact that the diamond surfaces are free of any marks of intensive mechanically-induced erosion (crescentiform and annular fissures, mechanogenic dulling of the faces and blunting and rounding of edges and apices) implies that no crystals from older intermediate collectors of marine-coastal genesis have been supplied to the placers. 
All the crystals studied contained nitrogen impurities in the forms of IaA (two nitrogen atoms), IaB (aggregated nitrogen) and "platelets" centres. The concentrations of these impurities are moderate, mostly varying within the range of $10^{19}-10^{20}$ atoms per $\mathrm{cm}^{3}$.

About $14 \%$ of the diamonds studied enclose mineral inclusions of ultramafic association. Diamonds with inclusions of olivine are most abundant, and account for $73 \%$ of the total number of inclusion-bearing diamond crystals. Much rarer in occurrence are diamonds with inclusions of chrome spinel $(9 \%)$ pyrope $(9 \%)$ and the simultaneous presence of both olivine and chrome spinel (9\%). Olivines show similar contents of the forsterite component $(91-94$ mol. \%, with a peak at 93 mol. \%) with insignificant admixtures of oxides: $\mathrm{Cr}$ (up to 0.09 wt. \%), Ca (up to 0.04 wt. \%) and $\mathrm{Ni}(0.27-0.49$ wt. \%). Noteworthy is the enormously high $\mathrm{Ni}$ concentration. Chrome spinels are very rich in $\mathrm{Cr}\left(62.5-64.5 \% \mathrm{Cr}_{2} \mathrm{O}_{3}\right)$, and contain less than $0.35 \% \mathrm{TiO}_{2}$. Garnets are mostly chromian pyropes $\left(\mathrm{Cr}_{2} \mathrm{O}_{3}=5.8-11.8\right.$ wt. \%; $\mathrm{CaO}=0.28-4.91$ wt. \%). No minerals of eclogitic association have been found in Ghanaian diamonds, which is in agreement with previous studies made by Stachel et al.

Carbon isotope composition of Birim diamonds lies within a range $-3.5 \%$ to $-8 \%$.

Heavy minerals. In the Birim placer diamond deposits, the set of essential minerals is represented by staurolite-ilmenite, ilmenite-staurolite, staurolite-rutile and, in one case, ilmenite-staurolitehematite associations. Essentially all the samples contain hematite and iron hydroxides as aggregate-type grains, in amounts of less than 10\%. Almandine, diopside, amphibole, tourmaline, kyanite, rutile and blue spinel are also present in moderate amounts. These minerals portray completely the character and composition of rocks developed in this region. Some ilmenites contain high $\mathrm{Mn}$ concentration, up to $2.4 \% \mathrm{MnO}$. No pyrope and the other "classical" kimberlite/lamproite indicator minerals indicator minerals have been found in the washing samples.

Bedrock "metakimberlites" and other volcanics. Some volcanic rocks were reported to be diamondiferous within the Birim area. They comprise subvertical dykes of NE orientation.

The Ajampesana A metakimberlite was crossed by an old trench, and no bedrock was observed there. The Beduwara dyke has been exposed by an open cut $100 \times 15 \mathrm{~m}$ and $20 \mathrm{~m}$ deep. These rocks form dykes which have been found only in small mines excavated by local miners. No fresh volcanic material is available now from these mines. Rocks making up the dykes are intensively metamorphosed, and have been subject to surface alteration within a mature crust of weathering. In the samples studied, the absence of any diamond indicator minerals, even those that are the most resistant to weathering crust conditions (chrome spinels), makes it impossible to classify these rocks as kimberlite or lamproite.

The heavy fraction from each dyke is composed mainly of ilmenite and rutile. Sparse grains of magnetite, hematite, staurolite and other minerals are present. Ilmenite from the Ajampesana A metakimberlite is characterized by a relatively low $\mathrm{FeO}$ content and by a high $\mathrm{Mn}$ concentration, $3.3-3.8 \% \mathrm{MnO}$. Rutile appears to be somewhat different than that contained in the alluvial samples, though its composition is the same and corresponds to the $\mathrm{TiO}_{2}$ stoichiometric formula. It is represented by fine-grained (less than $0.6 \mathrm{~mm}$ in size) elongated and prismatic grains with severely corroded surfaces. These latter often have light colored attachments of leucoxene and iron hydroxides. 
Diamonds were found in each dyke. They are colorless dodecahedra, octahedra and combination crystals. The diamonds show almost no traces of abrasion.

The Ajampesana B ultramafic dyke ("Lion pit") was excavated by local miners for diamonds at the contact of the dyke with the Birim shists. The ultramafic volcanics have a microcrystalline, lepidoblastic texture. It is composed of a microscaly aggregate of magnesian chlorite and talc, which encloses rather homogeneously distributed inclusions of almost colorless amphibole grains 0.01-0.05 $\mathrm{mm}$ in size, sometimes up to $0.1 \mathrm{~mm}$. The ultramafic volcanics also contain scarce leaflets of a colorless mica-like mineral substituted by chlorite in the grain margins (relics are preserved in the central parts of grains only), and isometric segregations composed of coarse-tabular (up to $0.5 \mathrm{~mm}$ ) chlorite, which, in some cases, show nearly isomorphic shapes and may be pseudomorphs after dark-colored minerals. In addition, rather coarse (up to $0.5 \mathrm{~mm}$ ) aggregate-type grains of yellowish-brown rutile are present in the sample; these grains feature irregular isometric or slightly elongated shapes with uneven boundaries. No mineralogical or structural features of kimberlite or lamproite can be distinguished now in these intensely weathered "ultramafic volcanics".

The rocks yield a rather low proportion of heavy minerals $(0.1-0.4 \%$ of the total weight of the samples); this heavy fraction is almost $100 \%$ rutile with attached chlorite. Rutile is in the form of elongated prismatic grains up to $0.6 \mathrm{~mm}$ along their axes. Cruciform twins are rather common. All the grains are extensively corroded; their color varies from reddish-brown to brownish-red. Single ilmenite and chlorite grains and amphibole aggregates were also noted in the heavy fractions. The composition of the ilmenite and rutile is the same as in the alluvial concentrate samples and in the other bedrock samples.

Despite the extremely high intensity of alteration, the distribution of the major elements in chemical composition (determined by silicate analysis) and some microelements (determined by X-ray fluorescent analysis) indicate that both rocks are probably ultramafic, based on the low $\mathrm{SiO}_{2}$ content, the rather low (for mature crusts of weathering) $\mathrm{Al}_{2} \mathrm{O}_{3}$ content and the low concentrations of incompatible elements $(\mathrm{Ti}, \mathrm{Nb}, \mathrm{Sr}$ ). High contents of $\mathrm{Al}, \mathrm{Fe}$ and $\mathrm{Zr}$ may be due to the accumulation of these elements in the zone of weathering.

Conclusions. Judging by the diamond morphology and intactness, the primary sources are located in the proximity of the known placer deposits. The presence of diamonds in the Beduwara dyke and the Ajampesana B "metakimberlite" indicates that these rocks are indeed primary diamondiferous rocks which may have been the source of diamonds in the alluvial placers. The primary nature of these rocks is still not identified. The diamonds from the placer deposits contain mineral inclusions of ultramafic association (olivine, chrome spinel and pyrope garnet). On the other hand, no kimberlite/lamproite indicator minerals were found in the diamondiferous rocks, and the diamonds in the placers are not accompanied by common indicator minerals, such as pyrope garnet, chrome spinel, chrome diopside and picroilmenite. Only high-manganese ilmenite may be considered as a probable diamond indicator mineral.

\section{References}

Stachel, T., Harris, Y.W., and Cartigny, P.,1995, Diamonds and their syngenetic mineral inclusions from the 2 GA Birimian deposits, Ghana, West-Africa: Sixth International Kimberlite Conference. Extended Abstracts. Novosibirsk, Russia, p. 578-580. 